\title{
Lecturers' Beliefs and Agency about Active Learning in English For Specific Purposes Classes
}

\author{
Huan Buu Nguyen \\ Can Tho University \\ Vietnam
}

\begin{abstract}
This paper examines how English for Specific Purposes lecturers changed their teaching strategies that align with their beliefs about active learning at a Vietnamese university. There is a growing interest in making changes in tertiary instructional practices to involve students in active learning in response to increasing international contexts. Significant reforms of higher education in Vietnam have called for the quality of education, particularly foreign language teaching and learning. Thus, it requires teachers to change not only thinking about new instructional ways but also role shift in improving student learning. However, there is a paucity of research into how science lecturers perceive their practice changes as improving student learning in interactive and dynamic ways. This paper draws on data collected as part of a qualitative action research study including interviews, classroom observations, and planning meetings over three-semester periods. The focus of this study is on the data which examined how five lecturers perceived and implemented active learning strategies. The findings indicate lecturers' positive beliefs about the change process and their growing awareness of the need for role changes in their practices, thereby associating change with their agency in the change process. Pedagogical implications for policymakers and ESP lecturers are also considered.
\end{abstract}

Keywords: agency; active learning; ESP; beliefs; change process

\section{Introduction}

Much research has been done about the role active learning plays in higher education over the last few decades as it is viewed as student engagement, participation in, and responsibility for their learning process (e.g., Bonwell \& Eison, 1991; Freeman et al., 2014; Mintzes \& Walter, 2020). From the constructivist student-centered approach to date there has been an increased emerging need for active learning in tertiary education in Vietnam and this trend influences how teachers change their beliefs and instructional practices (Prince, 2004). Yet, teaching at universities is mostly grounded on lecture mode (Nguyen, 2014), thus, the current shift from traditional lecture views towards a student-centered active 
learning approach is a real challenge for lecturers and students (Nguyen, Haworth, \& Hansen, 2019). Also, there appears to be little research into science teachers' agency about the active learning process in English for Specific Purposes classes to enhance student learning within the context in Vietnam. This paper therefore presents a new lens of active learning in the teacher change process that science lecturers perceived the need for change and then implemented their new strategies in their ESP classes.

To effect changes in instructional practices and to promote student active learning in response to increasing international contexts, the Vietnamese Government has called for role changes of lecturers. This guiding principle necessitates lecturers' innovative teaching strategies to enhance student learning, including their greater responsibility and participation in their learning process. In particular, the National Foreign Language Project 2020 have called for the quality of teaching and learning foreign languages, including English at all levels of education to meet the needs of students (Ministry of Education and Training, 2008). These strategic policies present a real challenge for lecturers since teaching practices at Vietnam higher education institutions have been lecture-based (Pham, 2010). Integrating more active learning strategies, therefore, involves substantial changes in the beliefs, roles, and decision-making of lecturers. Understanding such challenges, therefore, suggests that lecturers in ESP classes perceived themselves as agents of change in their teaching practices in line with new government policies.

This paper provides insights from a study that examined lecturer agency about the change process that aligns with their beliefs in ESP classes to enhance student learning. The research question that guided the study reported in this paper was: 'How do ESP lecturers change their teaching strategies in line with their beliefs about active learning?'

\section{The literature}

\subsection{Active Learning}

Research into active learning has indicated its role as an alternative to traditionalbased approach (e.g., Armbruster, Patel, Johnson, \& Weiss, 2009; Watters, 2014). Specifically, active learning strategies exert a strong impact on student learning (Prince, 2004). There are several perspectives on active learning in the literature. In this paper, two key features of active learning are discussed. Firstly, active learning refers to the notion of what students are engaging in doing activities and thinking about what they are doing (Bonwell \& Eison, 1991). Their view entails the vital role of higher-order thinking processes (e.g. analysis, synthesis and evaluation) as highlighted in Bloom's (1956) taxonomy. Once students are engaged as active participants in the learning process, their learning attitudes and skills may occur as a result (Smith, Sheppard, Johnson, \& Johnson, 2005). This constructivist view suggests that students are likely to take greater responsibility for and involvement in learning.

Secondly, active learning is that it "provides opportunities for students to talk and listen, read, write, and reflect as they approach course content through problem- 
solving exercises, information small groups, simulation, case studies, roleplaying, and other activities, all of which require students to apply what they are learning" (Meyers \& Jones, 1993, p. xi). In this definition, active learning is particularly associated with the integration of skills mediated by the lecturer to help students learn. Thus, active learning places a strong emphasis on the role of the lecturer (Arthurs \& Kreager, 2017; Auster \& Wylie, 2006; Keyser, 2000) and importantly, the implementation of new strategies such as problem-solving, technology advanced tasks, or evidence-based instruction (Strubbe, Stang, Holland, Sherman, \& Code, 2019). From these perspectives, active learning is viewed, for this study, as an interactive process in which students construct and utilize knowledge in critical and meaningful ways.

\subsection{Lecturer agency}

The notion of agency refers to the exercise of control over one's behavior (Bandura, 1997; Holland, Lachicotte Jr., Skinner, \& Cain, 1998); the power to act purposefully and reflectively (Inden, 2000); the power to make decisions that bring positive change (Moore, 2008); or the capacity to understand personal goals towards actions (Edwards, 2009). Bandura (1997) and Holland and his colleagues (1998) further describe agency as a causative interaction of self-efficacy beliefs influencing change (Water \& Gerson, 2007). From these perspectives, effective teaching is likely to depend upon or is driven by the teacher or lecturer agency. There is a growing interest in teacher agency in response to the call for curriculum and instruction change initiated by the government; therefore, teachers are likely to act their roles as 'agents of change' (Priestley, Biesta, \& Robinson, 2015), 'ecology' (Biesta, Priestley, \& Robinson, 2017), or 'agentic professionals' (Simpson, Sang, Wood, Wang, \& Ye, 2018). As its name suggests, teachers are believed to play an indispensable role within the social, political, and cultural-mediated contexts in which they work to effect changes (Willis, McGraw, \& Graham, 2019). Such agentic beliefs are associated with lecturer commitment (Tao \& Gao, 2017) and their passion for teaching. Lecturers, therefore, with a strong sense of agency can provide students with an effective learning environment, which contributes to their personal and social growth (Calvert, 2016; Tschannen-Moran \& Hoy, 2007; Tschannen-Moran \& Woolfolk Hoy, 2001). The present study reported in this paper examines how lecturers' sense of agency was modified over time.

\subsection{Lecturers' beliefs, Self-efficacy}

Despite a growing concern of content-based instruction taught through English as a challenge to lecturers and students in Asia (Feryok, 2008, 2012; Nunan, 2003), few studies have examined lecturers' beliefs about change concerning active learning strategies presented to students within the ESP teaching and learning context where lecturers language and science are Vietnamese (Nguyen, 2013). This study is about lecturers' beliefs about the change process and their implementation of active learning strategies.

Lecturers' beliefs refer to the ways that lecturers think about their actions (Clark \& Peterson, 1986; Dewey, 1933; Martin, Park, \& Hand, 2019). Beliefs influence lecturers' actions in specific classroom practices for the sake of enhancement of 
student learning (Dewey, 1933; Nespor, 1987; Pajares, 1992), including that of science education (Boesdorfer, Del Carlo, \& Wayson, 2019; Lumpe, Haney, \& Czeniak, 2000; Martin et al., 2019). Boesdorfer and colleagues (2019) reveal that science teachers' beliefs about student learning of science and their instructional practices are connected and that teachers' practices are viewed as enactment of what teachers believe is best for student learning. However, since beliefs are likely to be hard to change (Pajares, 1992), lecturers may need support and involved in new instructional activities that result in a change in their beliefs, knowledge, and practices (Bakkenes, Vermunt, \& Wubbels, 2010). In other words, belief change is likely to promote practice change (Clark \& Peterson, 1986; Cronin-Jones, 1991).

Self-efficacy plays an important part in understanding the impact of lecturers' beliefs and their instructional practices (Bandura, 1977; Hoy \& Miskel, 2001; Pajares, 1992). Bandura (1977) defines self-efficacy as "beliefs in one's capacities to organize and execute the courses of action required to produce given attainments" (p.3). In this definition, self-efficacy refers to a person's judgment of his or her potential success in performing a given task, as noted in Hoy and Miskel (2001), Hansen (2004), and Kazempour (2008). Self-efficacy beliefs are thus integral to teaching concerning motivation and student learning. Such beliefs help lecturers to "determine how much effort people will expend and how long they will persist in the face of obstacles and aversive experiences" (Bandura, 1977, p. 194). Other literature also supports the view that highlights the impact of selfefficacy beliefs on lecturer practice (Hoy \& Miskel, 2001; Pajares, 1996; Usher \& Pajares, 2008). If lecturers have strong beliefs in their capabilities, then they are motivated to accomplish their tasks by developing instructional activities or active learning strategies that are important and relevant to their student learning in specific subjects or disciplines.

\subsection{English for Specific Purposes and teacher change}

Over the last four decades, English for Specific Purposes has gained its increasing recognition in English language teaching and learning in science education (Basturkmen, 2006; Dudley-Evans \& St John, 1998; Khan, 2020) to meet the needs and interests of learners (Hutchinson \& Waters, 1987; Ramirez, 2015) within multifaceted contexts of life, including education. The terms 'learner-needs' 'goal-oriented', and 'process-oriented' all denote the defining characteristics of English for Specific Purposes (Kırkgöz \& Dikilitaş, 2018; Nunan, 2003). ESP instruction, therefore, entails lecturer knowledge of the interplay of complexities of student learning, course content, and instructional practices.

English for Specific Purposes, as its name and above features suggests, demands that lecturers should make changes in practices to ensure student learning in effective ways. To keep up with ever-changing globalized world of academia and work, English for Specific Purposes lecturers in Vietnamese tertiary context are no exception in shifting roles and making innovative instructional decisions to move students forward.

While science lecturers recognize English for Specific Purposes as a crucial part in their teaching practices, the challenges as teachers' lack of teaching skills, 
knowledge, and inadequate preparedness for the instruction are identified in the literature (e.g., Alsharif \& Shukri, 2018). In Vietnam, students with mixed-levels of English proficiency challenged lecturers in science classes. A more recent study about teacher beliefs about active learning by Nguyen and his colleagues (2019) has identified big class size, unqualified subject-specific lecturers; inactive students, and resources as key issues while experiencing change (Nguyen et al., 2019). Therefore, there is a pressing need for lecturers to tailor their instruction and syllabi, which in turn, drives them to change.

\section{The Study}

\subsection{Design and participants}

This paper reports on an aspect of a wider study that used qualitative action research undertaken at a university in the Mekong Delta, Vietnam to explore how lecturers in science classes implemented changes in line with beliefs about active learning and their role change. The criteria for selecting the lecturers focused on their similar tenure, professional and research knowledge, and English proficiency. However, these five science lecturers who were not trained with English for Specific Purposes teaching experienced new teaching strategies while endeavoring to improve their teaching practices through enhancing students' active learning. These lecturers were working in five different colleges at university voluntarily participated in the study. At the time of the study, years of teaching experience of the lecturers varied from 14 to 32, with an average of 21.8 years. In this research the researcher played a facilitative role, working alongside the lecturers to develop active learning activities and reflect on their change practices. Pseudonyms are used to protect lecturers' identities.

\subsection{Instruments}

Over the three-semester periods, data gathered through semi-structured interviews, observations, and planning meetings were electronically recorded. The first investigative tool focused on an in-depth examination of lecturers' beliefs about active learning and changes in their teaching practices. Extracts from observation and planning meetings were identified as the role change of lecturers and their decision-making process in line with their beliefs in the change process.

As action research focuses on bringing about changes and improving practice (Burns, 2010; Elliott, 1991; McNiff \& Whitehead, 2010), the present study qualitatively recorded ways that both the researcher and participating lecturers collaboratively planned, acted, observed, reflected, and made action plans for changes. These opportunities allowed the lecturers in this study to understand the benefits of change, increase their capacity for change, and enhance their learning and professional growth.

The lecturers were first interviewed at the beginning and at the end of the action research process where they expressed their beliefs about active learning, the impact of beliefs on their role changes in science teaching over time. Each interview lasted approximately one hour. The lecturers were then observed in each class once a week from four to six times over the three-semester period. Each 
fifty-minute observation of lecturers' lessons were video-recorded, transcribed, and translated into English. Observation categories of the five-stage lesson plan allowed lecturers to reflect on the effects of their role change in practice, and for the researcher to encourage further thinking and action plan through the key incidents in lecturers' practices. Following the class observation, planning meetings were set with each lecturer to revisit the action, reflect on or evaluate the change effects, and then develop new active learning strategies for subsequent classes. Follow-up interviews were finally conducted with the lecturers at the end of each semester of the study.

\subsection{Data analysis}

Interview data were analyzed using the thematic analysis (Boyatzis, 1998). This type of analysis helped identify categories and themes, as noted by Craig (2009) with reviewing data as 'units of meaning', as noted by Stringer (2008). These themes along with observation scenarios and planning meeting notes examined changes in lecturers' beliefs, roles and practices over time.

\section{Findings}

This section presents the findings from the qualitative action research examining how science lecturers experienced the change process in English for Specific Purposes classes. Analysis of data is organized into three themes identified as lecturers' beliefs about implementing active learning, awareness of role change, and their agency in the change process over time.

\subsection{Lecturers' beliefs about implementing active learning}

The first theme identified from interview data was that all of the participating lecturers believed active learning was related to student-centeredness and this trend was found to grow stronger in the implementation of change over time. For example, Tung said:

"I think active learning was useful although I had to do many things and spent hours preparing new lesson plans and problem-solving. In previous classes, I had not considered the answers to questions raised by students because they were passive (Tung, follow-up interview)"

These comments indicate the increased involvement of both the participating lecturer and his students in the co-construction of new knowledge.

Another lecturer revealed that the implementation of active learning was necessary because this awareness indicated their students' responsibility for learning sciences. In a planning meeting, this lecturer further noted that active learning could allow students to contribute their ideas to what was presented to them (Bach, planning meeting notes).

Initially, Tham believed that promoting active learning meant being studentcentered. She contended that 
"Active learning is focused on the role of the students, particularly how to help them build up new knowledge from previous experience and how to connect that knowledge"

Thus, Tham's view recognized the importance of high-order thinking that required students to utilize what they learned and expanded such learned knowledge for their new learning experience.

At the end of her action project, Tham confirmed her beliefs about active learning that fitted into her teaching. She said:

"Through students' attitudes, I realize that they like this course. They express more ideas, speak more in English, and participate in more activities in a friendly and collaborative way. They can make presentations in class well whereas previously they were not told to do so (Tham, follow-up interview)."

These above views suggest that these lecturers were more aware of students who were independent of their lecturers in learning new knowledge through interactions and implementation of technological resources. Their instructional change was therefore closely related to their motivation to promote student autonomy.

At the onset of the study, Bach associated change with the role of the students in their learning process. He said it was a real issue as active learning depends on student involvement and their accountability for their learning outcomes (Bach, initial interview). While participating in the change process, Bach acknowledged that active learning had fitted into his teaching and had been a positive experience up to this time:

"Active learning is needed because it has fitted my role. Previously, I lectured and my students listened. They only knew the literal interpretation by translating texts and were passive. They forgot many things. Now, I have my students do many activities; therefore, they can use words with various meanings to fit in the context of their discipline (Bach, follow-up interview)."

The theme of viewing students as active participants in their learning process happened again along with other interviewees about vocabulary teaching in context as a means of relating prior to new knowledge. Such changes in lecturers' beliefs indicated that the higher-order thinking he utilized could help students to learn more actively. Thus, students could learn, internalize their learning, and apply new knowledge.

For most lecturers, as change progressed, active learning had fitted into their teaching as a result of students' increased participation in activities planned as part of the study. One lecturer stated: 
"I do think active learning has been part of my lesson plans and would be sustained if more time was provided. Biology terms are the most complicated ones in this paper. Well, it is therefore through discussions with peers, students are expected to learn more (Tam, follow-up interview)."

Overall, despite some varying degrees of positive beliefs about active learning in the change process, their belief change to some extent could influence how they attempted alternative ways to get students involved in taking charge of their learning in English for Specific Purposes classes.

\subsection{Awareness of the role change}

The second theme was that the participating teachers were aware of their roles in the change process as they viewed themselves as facilitators of active learning. They indicated that they only provided students with basic knowledge and require them to find further information. The following extracts illustrate their views.

"I think now I act as a facilitator rather than a controller. Otherwise, students are still passive. I try to help them with ideas and keywords and make them think about what they want to study and to discuss" (Tung, follow-up interview)

It can be found that Tung shifted his roles in moving students beyond traditional ways of learning assigned tasks at different stages of his lessons and that by doing so, students as active participants of developing subject-specific knowledge could involve in learning and thinking about the tasks presented to them instead of being asked to do. At the end of the action plan, Tung positively reflected on his role change:

"I kept asking what students know and want, such as 'What else can you say about this?' rather than having them listen to me all the time as I did previously. In pairs or groups, they learned from interacting with others."

These comments suggest that Tung had changed his views on the lecturer-student relationship, which allowed students to take more active roles. By taking a facilitative role, he engaged students in a dialogue that entailed thoughtprovoking and shared ideas.

In line with beliefs about active learning as noted earlier, Bach indicated a shift between his roles as a knowledge provider, a lecturer, and a facilitator:

"The teacher has to master the vocabulary. Therefore, in the first lesson, I play the role of a guide. When students present ideas or opinions, I provide them with translating new terms. While students work in groups, I facilitate their tasks."

This reflects how Bach conceptualized active English for Specific Purposes teaching as engaging his students in an interactive learning process. 
Initially, Tham noted that by interweaving her roles, she was able to help move students beyond the passive learning they were used to. She said:

"I am a controller of in-class activities. In the role of an instructor, I assign them exercises and then correct their mistakes to help them know where they are. Besides, I act as a facilitator in leading group discussions."

Recognizing the need for a role shift from a controller to a facilitator during teaching, Tham further said that she wanted to help less able students in practicing English skills. Thus, by taking a facilitative role, Tham provided her students with an opportunity to speak more English since they were seen as owners of new knowledge in their learning process.

After she participated in the study, Tham revealed an increased awareness of her role change:

"I provide students with the knowledge and the way to approach that knowledge. However, I focus more on teaching them how to learn, depending upon the stages of the lesson. I have different roles such as being an observer, a facilitator, or an assessor. I think the role of a facilitator or a guide dominates."

These comments suggest that by taking a facilitative role, Tham perceived her students as active learners who were becoming more responsible for constructing their knowledge.

Two lecturers noted that towards the end of their participation in the study, they recognized the importance of the weaving of three roles in delivering their lessons. These role changes include a provider, a guide, and a facilitator at different stages of his lessons, as noted in the following two extracts:

"First, I take the role of a knowledge provider. Second, [I am] a guide who shows students how to find references, and a controller throughout activities. When students take advanced papers, they will be more autonomous and I will act as a facilitator." (My, planning meeting notes)

"I teach students vocabulary and content knowledge. During the group discussion and exercises, I position myself as a facilitator. When students do not know what to do next for a given task, I play the role of a guide. Towards the end of the course, well, I talk less but my students talk more during the lesson" (Tam, planning meeting notes)

These reflections suggest that the lecturers played more supportive roles as time progressed as they focused upon the active roles of the students as autonomous learners instead of seeing them as passive recipients of knowledge. They also saw that the lecturer-student relationships were established to contribute to more active learning of students in their classes. 


\subsection{Self-efficacy and agency driving change}

\section{Self-efficacy}

The participating lecturers expressed varying degrees of self-efficacy, which is a key component of personal beliefs about making changes.

They expressed a strong sense of self-efficacy about the change process. While Tung and Bach believed that the need for change was part of their work or responsibility, two other lecturers (Tham and My) expressed their sense of selfefficacy to make changes in pedagogical practices, particularly teaching strategies. One good example that reflects personal efficacy is the case of Bach who said,

"Lecturers have to find their ways to teach their papers. As a teacher, academic advisor, or supervisor, I know what to do for my students in learning this paper" (Bach, follow-up interview)

This quote suggests that Bach's sense of self-efficacy was based upon his teaching competence and roles rather than external or contextual influences by the university and college. Also, he became aware of not only general teaching efficacy but also English for Specific Purposes teaching efficacy that could drive him to make changes in his teaching practices.

With further regard to the self-efficacy beliefs of lecturers, Tham's case is an interesting example. She expressed her self-efficacy beliefs about her planning of new teaching strategies,

"I strive to engage my students in practicing as many exercises as possible to acquire sufficient English and find their ways to learn" (Tham, follow-up interview)

Tham's assertion reflected her dedication to change in active learning practice as she viewed students taking responsibility for their learning process. Such beliefs may influence the choices of the strategies she could make, which were relevant to the needs of her students.

In contrast, Tam's view on self-efficacy expressed how change related to personal and professional pride, before she implemented the change process. She said,

"I want my students to get through what I present to them. It would be my shame if my students did not understand my lesson" (Tam, followup interview).

Her response perhaps came as much from her expectations of herself as a teacher as from her teaching philosophy.

Agency drives change

All lecturers believed that they were agents of change in the implementation process of change in English for Specific Purposes science classes. 
Evidence of responsibility and roles about change can be seen in the case of Tam who said,

"If I do not make any changes in my ways, students will not learn much. I always want to help them to learn better and to be a role model" (Tam, follow-up interview).

In Tam's case, she held a strong sense of agency about student learning. What she expected students to see her as a role model seemed to reflect not only the construction of identity about student learning outcomes but also her identity about moral values she could perceive.

Tham also revealed that she had a strong sense of agency about his professional identity. She said,

"If I do not make any changes in teaching, I will be left behind and cannot improve my teaching" (Tham, follow-up interview).

Tham viewed herself as a person who was ready to change. Her teaching philosophy of being an agent of change, as a science lecturer perhaps came from the strong link between the teaching goals set for her and her strong sense of professional identity, which could bring about change in her classroom practices. Inherent in Tham's view concerning her role as being an agent of change was also the commitment she had to drive changes that allowed students opportunities to learn.

My's strong sense of agency demonstrated that his commitment and determination to make changes in his teaching profession was related to his role as an agent of change. He said,

"If the University does not provide any support, I will still make changes."

In My's words, he believed change was more likely to come from the lecturer himself rather than being contingent upon the institution. Unlike other lecturers in the present study, he believed change was a major part of his professional goals and closely linked with his identity as a science lecturer. He said,

"Change is expected to perfect my desired goals - bringing students to a higher level. Moreover, seeing students enjoy working with their businesses is an intellectual capital for me" (My, follow-up interview).

His personal goals for student learning and their future work drove him to change while implementing new instructional practices.

Aligned with the beliefs about active learning noted earlier, the science lecturers were observed while implementing more active and interactive activities in their English for Specific Purposes classes, as evidenced in the following extracts of observation notes. 
Initially, Tung focused on teaching reading and speaking activities as two integral parts of his change process. He had students seat in groups of five and complete the reading task for ten minutes. In guiding students to interact with other peers, he and the researcher provided them some prompts, moved around the class to check if they needed help (Tung, observation notes). In a planning meeting, Tung shared that he now understood reading for main ideas was essential because students needed an exact content knowledge (planning meeting). Near the end of the study, Tung utilized interactive ways such as panel discussion, brainstorming, and concept mapping to allow his students to take more active roles, as shown below.

"Each group member [student] first presented one section on 'Bacteria growth phases'. Students were asked to brainstorm some ideas related to each of the five phases (from lag to death phases). Then, they were given some new words and their meanings for clarity. Later, students were asked to link ideas and to develop the logic of the topic" (Tung, observation notes)

One can see that Tung shifted his role to a facilitator while encouraging students to speak more English. During the planning meeting, he said these new strategies could expose students to a deeper thinking about the lesson.

Likewise, at the beginning of the project, Bach stated that reading and translation were key to his teaching. He contended that these two skills in chemistry were needed to assist students in understanding technical terms (Bach, planning meeting), as presented in the observation notes:

"Students were asked to read online a short text on chemistry for two minutes and then to translate into Vietnamese. In groups of four, they list the major points or ideas and then each group leader/ representative presents their completed task." (Bach, observation notes \#1)

Bach further provided his students with an opportunity to take greater responsibility for their learning through watching short video clips of the 'Human body and life process'.

"The teacher had students watch a video clip, 'Biology: Seven life processes'. The time for the task is four minutes. Students were asked to complete the blanks provided on the blackboard. The teacher replayed the recording two times. Then, he asked students to read out loud the answer for each slot of the blanks to answer the questions mentioned on the board." (Bach, observation notes \#2)

Similar to Back, Tham used reading and translation strategies in her class. However, as change occurred, she put students into interactive group work activities through brainstorming and concept mapping as she thought these two strategies provoked student thinking, as noted below. 
"The teacher asked students to brainstorm what factors affect the development and growth of trees. Students were then asked to connect ideas using maps. The teacher finally had students discussed with their peers and report the final work" (Tham, observation notes \# 4)

Through reflections, Tham acknowledged the benefits of collaborative undertaking with the researcher

"This co-working research is useful because it allows me to change a lot and forward my professional growth. Action means improvement and commitment to inquiring into classroom practice. I think I will continue new ways to make students learn better" (Tham, planning meeting)

From Tham's joint decision-making, it can be concluded that she understood the effects of changes in practice were in close connection with professional growth.

As part of implementing active learning, Tung used a questioning technique, matching, and reflective writing. These activities aimed to provide students with more opportunities to take more active roles in their learning (planning meeting). Observation notes below illustrated how Tung initiated the changes.

"Students were asked to tell what they knew about the cell (definition, functions and history) before watching slides of 'Parts of the cell'. In pairs, students were asked to observe the diagram, answer true-false questions, read the passage, and translate these segments into Vietnamese. Pronunciation of new words was included" (Tung, observation notes \#2)

Thus, Tung believed that the use of questioning accompanying video clips helped students learn. This practice indicates that he integrated all English language skills into the lesson to enhance students' speaking opportunities and familiarize them with critical thinking. He went on to explain that when students worked in pairs, they tended to feel more relaxed and to interact with other students (planning meeting).

Throughout the study, Tung was more aware of the usefulness of the role of the students as active learners while positioning himself as a facilitator, as illustrated in the following episode

"Tung had students do the matching exercise on two cell categories (prokaryotic and eukaryotic). He pointed to three students who were completed the task and checked their answers. Students then presented their work. Then, Tung explained cell parts illustrated by a picture" (Tung, observation notes \#3).

The observed changes in Tung's strategies indicated that he considered students to be the center of the learning process. In particular, he asked students to write a short passage about the topic just presented and indicated he would continue to use journal writing as a lesson closure. He shared that this strategy not only enabled students to think about what they learned and improve writing skills as 
well but also allowed him to reflect on the effects of his new actions on student learning (planning meeting).

Tung also expressed his positive views on the change process about active learning:

"It is a good opportunity for me not only to learn more about the methods to teach this paper but also to gain other perspectives about teaching. After sharing experiences with you, I learned to make the syllabus available to students from the very beginning of the class because I can save time for other class activities; and the syllabus offers students a whole picture of what is going on within the whole year." (Tung, follow-up interview)

Throughout the interactions, Tung learned more about other aspects of teaching practice, thereby nurturing his personal and professional growth.

Tam showed how she developed her teaching strategies over the semester of her participation through the use of video clips, pictures, and reflective writing to engage students in taking more active roles. Her changes are described in the following scenarios.

"Tam had students watch an online broadcast on tiger shrimp and fish base. Students observed, took notes, and identified key concepts from the picture of a fish. Time for the listening and observing task was three minutes. Students were asked to jot down the names of thirteen parts of a fish. Then Tam had them free practice." (Tam, observation notes \#3)

"Before ending her class, Tam asked students to write reflections on 'fish morphology.' Time for this task was ten minutes." (Tam, observation notes \#4)

The observed changes illustrated how Tam employed new active learning strategies in the change process to enhance students' listening and writing, promote lecturer-student interactions, and particularly her new understanding of the value of collaborative involvement.

\section{Discussion}

The present study contributes to the lecturer agency about active learning literature in language and teaching of English as a foreign language, particularly involving lecturers in integrating English skills with subject content as a result of working alongside with the researcher. In understanding the need to place students in the center of their learning, the science lecturers change to view themselves as facilitators rather than traditional lecturers. Teacher change in this study was found to be a dynamic and collaborative process in that the stages of developing, implementing, reflecting, and then planning further actions occurred cyclically.

Over the semester periods, the implementation of active learning strategies reflected the intricacies of lecturers' strong beliefs bout change and increased 
awareness of change about their role shifts. In particular, it is interesting to note that in the collaborative change process, the lecturers' beliefs about active learning were consistent with the ways they changed their practices. Their beliefs support the literature that indicates the value of recognizing the active roles for students in their learning process (Bonwell \& Eison, 1991; Mintzes \& Walter, 2020). The insights that these lecturers had were developed through interviews, observations, and planning meetings. Despite slight variations within their views on active learning, they came to understand the need to shift their teaching roles from lecturers to facilitators of student learning or act interwoven roles at different stages of their lessons in the change process, thereby encouraging students to voice their ideas, select and construct new knowledge. This awareness is consistent with the literature on learning space design in higher education (Harrop \& Turpin, 2013; Savin-Baden, 2008), indicating that informal learning spaces allow students to have greater engagement in active learning.

The varying degrees of lecturers' self-efficacy were found to drive lecturers to make changes in their English for Specific Purposes teaching practices. While some lecturers perceived the need for change as part of their work and responsibility, others expressed their self-efficacy to make changes in pedagogical practices, particularly planning new strategies. Such beliefs were articulated in line with changed practices as they viewed themselves as agents of change, reflecting their strong commitment of the lecturers. It may be that their sense of self in enhancing student learning was intertwined with their beliefs about meeting the needs of students. This finding is important because their beliefs about active learning were more likely to be driven by their personal and professional identities. Agency and identity are closely connected (Beauchamp \& Thomas, 2009; Holland et al., 1998; Tao \& Gao, 2017; Wenger, 1998); therefore, once lecturers' beliefs changed, they were likely to reconceptualize or change roles and embark on experimenting with agentic teaching practices to promote student learning.

\section{Conclusions}

This study examined lecturers' beliefs and agency about how active learning was utilized in English for Specific Purposes classes at a university. The findings of this study contribute to agency literature about science teaching at a tertiary nonwestern context, particularly in Vietnam, in several ways. This study enhances understanding of the meaning of teacher change and its close connection with the process of learning and professional growth. The lecturers' reflections on the change process provided insights into the impact of lecturers' beliefs on their decision-making processes. The potential to implement new approaches has expanded the theory of change in science teaching.

This research illustrates how action and change can occur in Science classes in Vietnam, thereby promoting further investigation into how lecturers' beliefs about change influence their agency. In other words, lecturers of different disciplines could consider ways to reflect on their practices and enhance their beliefs about the capacity for change over time. As a result of such benefits, more lecturers may move forward by participating in qualitative action research 
projects or initiatives on a large scale. Awareness of the nature of the lecturer agency about active learning raises some implications for policymakers and ESP lecturers. Policymakers should consider providing lecturers with high demands for change and better resources to ensure change occurs and becomes part of lecturers' personal and professional growth. As belief change could heighten their self-efficacy through active learning strategies, lecturers should be encouraged to research into improving their practice by observing how other academic colleagues teach their papers. Thus, these beliefs together with their roles could influence and inform their future actions. The lecturers can discover the worth of collaborating with others through conducting action research into how active learning strategies that change their existing practices.

\section{References}

Alsharif, D., \& Shukri, N. (2018). Exploring pedagogical challenges of ESP teachers at a Saudi Arabian university. International Journal of Asian Social Science, 8(10), 841855. http://dx.doi.org/10.18488/journal.1.2018.810.841.855

Armbruster, P., Patel, M., Johnson, E., \& Weiss, M. (2009). Active learning and studentcentered pedagogy improve student attitudes and performance in introductory biology. CBE-Life Sciences Education, 8(3), 203-213. http://dx.doi.org/10.1187/cbe.09-03-0025

Arthurs, L. A., \& Kreager, B. Z. (2017). An integrative view of in-class activities that enable active learning in college science classroom settings. International Journal of Science Education, 39(15), 2073-2091. http:/ /dx.doi.org/10.1080/09500693.2017.1363925

Auster, E. R., \& Wylie, K. K. (2006). Creating active learning in the classroom: A systematic approach. Journal of Management Education, 30(2), 333-353. http:/ / dx.doi.org/10.1177/1052562905283346

Bakkenes, I., Vermunt, J. D., \& Wubbels, T. (2010). Teacher learning in the context of educational motivation: Learning activities and learning outcomes of experienced teachers. Learning and Instruction, 20(6), 533-548. http:/ / dx.doi.org/10.1016/j.learninstruc.2009.09.001

Bandura, A. (1977). Self-efficacy towards a unifying theory of behavioral change. Psychological Review, 84(2), 192-215.

Bandura, A. (1997). Self-efficacy: The exercise of control. New York, NY: Freeman.

Bandura, A., Davidson, F. W., \& Davidson Films. (2003). Bandura's social cognitive theory an introduction [[videorecording] 1 videodisc (37 min.)]. Bendigo, Vic.: VEA.

Basturkmen, H. (2006). Ideas and options in English for Specific Purposes: Lawrence Erlbaum Associates, Publishers.

Beauchamp, C., \& Thomas, L. (2009). Understanding teacher identity: An overview of issues in the literature and implications for teacher education. Cambridge Journal of Education, 39(2), 175-189. http:/ / doi.org/10.1080/03057640902902252

Belcher, D. (2004). Trends in teaching English for Specific Purposes. Annual Review of Applied Linguistics, 24, 165-186.

Biesta, G., Priestley, M., \& Robinson, S. (2017). Talking about education: Exploring the significance of teachers' talk for teacher agency. Journal of Curriculum Studies, 49(1), 38-54. http://dx.doi.org/10.1080/00220272.2016.1205143

Bloom, B. (1956). Taxonomy of educational objectives Book 1: Cognitive domain: Longman. 
Boesdorfer, S. B., Del Carlo, D. I., \& Wayson, J. (2019). Secondary science teachers' reported practices and beliefs on teaching and learning from a large national sample in the United States. Journal of Science Teacher Education, 30(8), 815-837. http://dx.doi.org/10.1080/1046560X.2019.1604055

Bonwell, C. C., \& Eison, J. A. (1991). Active learning: Creating excitement in the classroom. ERIC Digests.

Boyatzis, R. E. (1998). Transforming qualitative information: Thematic analysis and code development Thousand Oaks, California: SAGE Publications, Inc.

Burns, A. (2010). Doing action research in English language teaching: A guide for practitioners. New York, NY: Routledge.

Calvert, L. (2016). The power of teacher agency. Journal of Staff Development, 37(2), 51-56.

Capel, S., Leask, M., \& Turner, T. (Eds.). (2009). Learning to teach in the secondary school: A companion to school experience. London, New York: Routledge.

Clark, C. M., \& Peterson, P. L. (1986). Teachers' thought processes. In M. C. Wittrock (Ed.), Handbook of research on teaching (3rd Ed.) (pp. 255-296). New York: Macmillan.

Craig, D. V. (2009). Action research essentials. California: Jossey-Bass.

Cronin-Jones, L. L. (1991). Science teacher beliefs and their influence on curriculum implementation: Two case studies. Journal of Research in Science Teaching, 28(3), 235-250.

Dewey, J. (1933). How we think. Boston: D.C. Heath.

Drever, E. (1997). Using semi-structured interviews in small scale research: A teacher guide. Glasgow: Scottish Council for Research in Education.

Dudley-Evans, T., \& St John, M. J. (1998). Developments in English for Specific Purposes: A multi-disciplinary approach. Cambridge: Cambridge University Press.

Edwards, A. (2009). From the systemic to the relational: Rational agency and activity theory. In A. L. Sannino, H. Daniels \& K. D. Gutierrez (Eds.), Learning and Expanding with activity theory (pp. 197-211). Cambridge Cambridge University Press.

Elliott, J. (1991). Action research for educational change: Developing teachers and teaching: Open University Press.

Feryok, A. (2008). The impact of TESOL on maths and science teachers. ELT Journal, 62(2), 123-130. http://dx.doi.org/10.1093/elt/ccl054

Feryok, A. (2012). Activity theory and language teacher agency. The Modern Language Journal, 96(1), 95-107. http://dx.doi.org/10.1111/j.1540-4781.2012.01279.x

Freeman, S., Eddy, S. L., McDonough, M., Smith, M. K., Okoroafor, N., Jordt, H., \& Wenderoth, M. P. (2014). Active learning increases student performance in science, engineering, and mathematics. Paper presented at the Proceedings of the National Academy of Sciences.

Gillham, B. (2005). Research interviewing: The range of techniques. New York, NY: Open University Press.

Hall, L. A. (2005). Teachers and content area reading: Attitudes, beliefs and change. Teaching and Teacher Education, 21(4), 403-414. doi: https://dx.doi.org/10.1016/j.tate.2005.01.009

Hansen, S. (2004). An investigation of English teacher efficacy beliefs: Subject-specificity, subject-congruency, and associated factors. Massey University, Palmerston North, New Zealand.

Harrop, D., \& Turpin, B. (2013). A study exploring learners' informal learning space behaviors, attitudes, and preferences. New Review of Academic Librarianship, 19(1), 58-77. http:/ /dx.doi.org/10.1080/13614533.2013.740961 
Holland, D., Lachicotte Jr., W., Skinner, D., \& Cain, C. (1998). Identity and agency in cultural worlds. Cambridge, MA: Harvard University Press.

Hoy, W. K., \& Miskel, C. G. (2001). Educational administration: Theory, research, and practice (6th Ed.). New York, NY: McGraw-Hill Higher Education.

Hutchinson, T., \& Waters, A. (1987). English for specific purposes: A learner-centred approach. Cambridge: Cambridge University Press.

Inden, R. B. (2000). Imagining India. Bloomington, IN: Indiana University Press.

Kazempour, M. (2008). Exploring attitudes, beliefs, and self-efficacy of pre-service elementary teachers' enrolled in a science methods course and factors responsible for possible changes. (Ph.D.), Indiana University.

Keyser, M. W. (2000). Active learning and cooperative learning: Understanding the difference and using both styles effectively. Research Strategies, 17, 35-44. http:/ /dx.doi.org/10.1016/s0734-3310(00)00022-7

Khan, M. O. (2020). Necessity of ESP (English for Specific Purposes) courses for medical and science students at Najran University, Saudi Arabia: An exploratory-cum remedial study. Theory and Practice in Language Studies, 10(2), 208-217. http://dx.doi.org/10.17507/tpls.1002.09

Kırkgöz, Y., \& Dikilitaş, K. (2018). Key issues in English for Specific Purposes in higher education (Vol. 2). Switzerland: Springer.

Lumpe, A. T., Haney, J. J., \& Czeniak, C. M. (2000). Assessing teachers' beliefs about their science teaching context. Journal of Research in Science Teaching, 37(3), 275-292. http://dx.doi.org/10.1002/(sici)1098-2736(200003)37:3\%3C275::aidtea4\%3E3.0.co;2-2

Martin, A., Park, S., \& Hand, B. (2019). What happens when a teacher's science belief structure is in disequilibrium? Entangled nature of beliefs and practice. Research in Science Education, 49, 885-920. http://dx.doi.org/10.1007/s11165-017-9644-0

McNiff, J., \& Whitehead, J. (2010). You and your action research project (3rd Ed.): Routledge.

Meyers, C., \& Jones, T. B. (1993). Promoting active learning: Strategies for the college classroom. San Francisco: Jossey-Bass Publishers.

Ministry of Education and Training. (2008). Teaching and learning foreign languages in the national education system from 2008 to 2020. Hanoi: Vietnam Retrieved from Retrieved from http:/ / tailieu.vn/doc/de-an-day-va-hoc-ngoai-ngu-trong-hethong-giao-duc-quoc-dan-1331102.html.

Mintzes, J. J., \& Walter, E. M. (2020). Active learning in college science. California, CA, USA: Springer.

Moore, F. M. (2008). Agency, identity, and social justice education: Preservice teachers' thoughts on becoming agents of change in urban elementary science classrooms. Research in Science Education, 5(38), 589-610. http://dx.doi.org/10.1007/s11165007-9065-6

Nespor, J. (1987). The role of beliefs in the practice of teaching. Journal of Curriculum Studies, 19(4), 317-328.

Nguyen, H. B. (2013). Beliefs about support for teacher change in English for Specific Purposes university classes. New Zealand Studies in Applied Linguistics, 19(2), 3648.

Nguyen, H. B. (2014). Teacher change in science education in a Vietnamese university. (Ph.D.), Massey University, Palmerston North, New Zealand.

Nguyen, H. B., Haworth, P., \& Hansen, S. (2019). Challenging ESP teacher beliefs about active learning in a Vietnamese university. Teacher Development, 23(3), 345-365. http:/ /dx.doi.org/10.1080/13664530.2019.1598481 
Norton, B. (2000). Identity and language learning: Gender, ethnicity and educational change: Pearson Education Limited.

Nunan, D. (2003). The impact of English as a global language on educational policies and practices in the Asia-Pacific region. TESOL Quarterly, 37(4), 589-613. http:/ / dx.doi.org/10.2307/3588214

Pajares, M. F. (1992). Teachers' beliefs and educational research: Cleaning up a messy construct. Review of Educational Research, 62(3), 307-332. http:/ / dx.doi.org/10.3102/00346543062003307

Pajares, M. F. (1996). Self-efficacy beliefs in academic settings. Review of Educational Research, 66(4), 543-578. http://dx.doi.org/10.3102/00346543066004543

Pham, N. T. (2010). The higher education reform agenda: A vision for 2020. In G. Harman, M. Hayden \& T. N. Pham (Eds.), Reforming higher education in Vietnam: Challenges and priorities (Vol. 29, pp. 51-64): Springer.

Priestley, M., Biesta, G. J. J., \& Robinson, S. (2015). Teacher agency: An ecological approach. London: Bloomsbury.

Prince, M. (2004). Does active learning work? A review of the research. Journal of Engineering Education, 93(3), 223-231. http://dx.doi.org/10.1002/j.21689830.2004.tb00809.x

Ramirez, C. G. (2015). English for Specific Purposes: Brief history and definitions. Revista de Lenguas Modernas, 23, 379-386. http:/ / dx.doi.org/10.15517/rlm.v0i23.22359

Savin-Baden, M. (2008). Learning spaces: Creating opportunities for knowledge construction in academic life: The Society for Research into Higher Education \& Open University Press, The McGraw-Hill companies.

Simpson, A., Sang, G., Wood, J., Wang, Y., \& Ye, B. (2018). A dialogue about teacher agency: Australian and Chinese perspectives. Teaching and Teacher Education, 75, 316-326. http:/ / dx.doi.org/10.1016/j.tate.2018.07.002

Smith, K. A., Sheppard, S. D., Johnson, D. W., \& Johnson, R. T. (2005). Pedagogies of engagement: Classroom-based practices. Journal of Engineering Education, 94(1), 87-101. http:/ / dx.doi.org/10.1002/j.2168-9830.2005.tb00831.x

Stringer, E. (2008). Action research in education (2nd Ed.). New Jersey: Pearson Education, Inc.

Strubbe, L. E., Stang, J., Holland, T., Sherman, S. B., \& Code, W. (2019). Faculty adoption of active learning strategies via paired teaching: Conclusions from two science departments. Journal of College Science Teaching, 49(1), 31-39. http:/ / dx.doi.org/10.2505/4/jcst19-049-01-31

Tao, J., \& Gao, X. (2017). Teacher agency and identity commitment in curricular reform. Teaching and Teacher Education, 63, 346-355. http://dx.doi.org/10.1016/j.tate.2017.01.010

Tschannen-Moran, M., \& Hoy, A. W. (2007). The differential antecedents of self-efficacy beliefs of novice and experienced teachers. Teaching and Teacher Education, 23(6), 944-956. http:/ /dx.doi.org/10.1016/j.tate.2006.05.003

Tschannen-Moran, M., \& Woolfolk Hoy, A. W. (2001). Teacher efficacy: Capturing an elusive construct. Teaching and Teacher Education, 17(7), 783-805.

Usher, E. L., \& Pajares, M. F. (2008). Sources of self-efficacy in school: Critical review of the literature and future directions. Review of Educational Research, 78(4), 751-796. http:/ / dx.doi.org/10.3102/0034654308321456

Water, J. G., \& Gerson, H. (2007). Teachers' personal agency: Making sense of slope through additive structures. Educational Studies in Mathematics, 65(2), 203-233. http://dx.doi.org/10.1007/s10649-006-9048-y 
Watters, N. (2014). An exploration of the concept and practice of active learning in higher education. (Ph.D.), University of Glasgow, UK.

Wenger, E. (1998). Communities of practice: Learning, meaning and identity. Cambridge: Cambridge University Press.

Willis, J., McGraw, K., \& Graham, L. (2019). Conditions that mediate teacher agency during assessment reform. English Teaching Practice and Critique, 18(2), 233-248. http://dx.doi.org/10.1108/ETPC-11-2018-0108 